\title{
Women's Groups in the Former Yugoslavia: Working with Refugees
}

\author{
Maja Korac
}

The horrors of the war in the Former Yugoslavia and the suffering of more than four million refugees and internally displaced persons, mostly women and children, have already been well-documented (UNHCR 1993). The new states of ex-Yugoslavia have taken the brunt of the refugee burden. According to the UNHCR, as of July 1993 the estimated total of asylum seekers from the former Yugoslavia in European countries was 750,000 , whereas $3,380,000$ were displaced persons and refugees within the region of the former Yugoslavia itself.

Local governments, NGOs, as well as international humanitarian organizations, are providing aid and helping refugees. Although the humanitarian aid is financially significant, this article will attempt to question a problematic assumption in refugee policythat refugees are "taken care of" as long they are free from the immediate dangers that forced them to flee. The pitfalls of such a policy, especially as applied to refugees fleeing from ethnic conflict, become immediately apparent when the policy is contrasted with the political context of the Yugoslav conflicts, as well as the experiences, needs, and problems of refugees themselves.

The ultimate search for ethnic-national "oneness" and the creation of a hated "other" led to the violent disintegration of the Former Yugoslavia. Millions of refugees and internally displaced persons now face the problem of reconciling their own notion of belonging and identity with the new realities of their lives. Many refugees have close relatives whose ethnic background differs from their own, or are themselves in ethnically-mixed marriages. As refugees, they live in ethnically-mixed refugee camps in the newly-recognized states in the region

Maja Korac is a Ph.D. Candidate, Sociology, York University and a Doctoral Associate, CRS. that was Yugoslavia, where their ethnic group differs from the majority of the population. As such, they are frequently perceived as "enemies." Additionally, as a result of war, the economic crisis worsened, ${ }^{1}$ transforming all refugees, regardless of their ethnicity, into "others" perceived as a heavy, unbearable burden to the host governments. Refugees from minority ethnic groups became even more stigmatized.

In a political context in which almost all regional host governments ${ }^{2}$ are involved, war and the psychological, political, or economic violence against civilians who became refugees, continue. Refugees are being used and manipulated by the host governments according to current political objectives.

Early in the crisis, women's groups ${ }^{3}$ began to direct their energies into opposing chauvinism, militarism, and manipulation of refugees for political purposes. They also made an effort to raise awareness among citizens of their states that refugees are victims of the political regimes, and that citizens should prevent their governments from further victimization of the innocent. In Serbia, for example, women's groups distributed a petition to citizens entitled Let Us Make the Lives of the Refugees Visible, ${ }^{4}$ which stated:

Refugees are here, in Serbia. The government has placed them in the camps, far away from villages and cities. Women, children and elderly live there according to the rules unknown to the majority of the citizens of Serbia ... The lives of the refugees, true victims of this war remain invisible. They are remitted to the soulless bureaucracy of the camps, condemned to endless victimization. Citizens of Serbia, refugees are not responsible for our miserable lives. The regime of Slobodan Milosevic is guilty for their and our misery. Let us demonstrate our solidarity with refugees. Let us visit them at the camps. Let us denunciate violation of their human rights. Let us demand that the international humanitarian aid reaches them. Let us ask them how they are!

These relatively small but energetic groups of women ${ }^{5}$ (whose activities are based on an inclusive politics which cuts across ethnic boundaries) have defined their approach to refugees as, first and foremost, to work with them, rather than for them. In this way, these groups are making a significant effort to overcome the paternalistic undertones of official refugee policy and projects ensuing from it. Such an effort stems from the belief that refugees should not be encouraged to reconcile themselves to the roles of victims and passive recipients of humanitarian aid. Moreover, since a vast majority of refugees in the Former Yugoslavia are women and children ${ }^{6}$ (whose experience with the conflicts, militarization, and violence in war is specific to their position in the social structure), these groups approach women refugees with a strong sense of women's solidarity and an insight into their specific needs and problems.

The women's centres' activists? search for women refugees, who are survivors of war rape, in the medical institutions where the women come for abortions or to give birth. The activists organize to meet the women survivors' needs through counselling by trained volunteers or through the provision of financial aid. ${ }^{8}$ In a few cases, they have tried to provide for the basic needs of the women war rape survivors by paying for their passage to foreign countries, paying their rent, or taking care of their babies. The activists act as mediators between the survivors of war rape, institutions, and families. Further, the centres provide individual (and occasionally group) counselling to refugee women who are housed in the camps or hosted by individual families. ${ }^{9}$ The activists provide 
placement and legal services for women refugees. They have also provided a number of refugee women with theatre tickets, organized group shopping trips and, in some cases, paid for extra medical needs such as glasses or dental work. Additionally, they have organized various projects with women refugees to produce handicrafts and art objects, both to restore the refugee women's cultural heritage, and to provide them with some financial support. ${ }^{10}$ The "I Remember" project creates an alternative women's history that aims to encourage an exchange of experiences among refugee women, and between refugee and activist women. In it, women remember not only the horrors of the war but prewar times as well, so as to establish defensive mechanisms against the hatred and misery around them.

A number of refugee women have joined the women's groups. Mira, ${ }^{11}$ a Bosnian Serb refugee from Mostar, now a coordinator of the refugee program in the Women in Black group in Belgrade, related how she learned of Women in Black and their silent weekly anti-war protests from a woman journalist who interviewed her upon her arrival in Belgrade.

And I went that Wednesday [to attend an anti-war protest] and since then I didn't go maybe twice ... I remember that meeting when I told them [Women in Black]: none of us refugees want you to give us something, we want to earn it, to get our self-respect back. The initial idea for me was an episode in front of the Serbian Red Cross office. It was a cold wind, we were in a long line-up outside the office. A girl who was working there turned the heater towards her, every ten minutes she lit a cigarette and didn't do anything in the meantime, a really horrible situation. Then a woman in a red coat said after the tenth cigarette: "Could you please hurry it up a bit, it's really cold outside and I have a small child I left alone at home." The girl working there said angrily to all of us in the line-up: "Because of that woman in red no one is going to get anything today." The worst of it was that no one in the line-up took the side of the woman in red, as if we had never been human, as if we had never had dignity. They said to her [the woman in red]: "Get out, we won't get anything because of you." To me, the worst of it was that all of us in the line-up had totally lost our human dignity. And I somehow linked it to the fact that we were now reduced to receivers of aid. Because we are just receiving the aid you start to see it as a charity, that's why most of the refugees feel the way they do. Only if we'll have a chance to earn something, we'll get our self-confidence back and in fact that process of returning us to normal trends, as normal as it gets, can help. Also, 1 felt very bad because I couldn't work, besides the huge amount of time you have during a day, you have too much time to think about some events in the war and before the war that hurt, when everything that hurts, hurts all day. You also have the need to work and earn. That's the only way you can decide about your life .... After some talks, when I told them [Women in Black] all that, and talked with Jadranka [another refugee activist in Women in Black], we came up with the idea that we should try to do something which will allow women to earn something, no matter how little, and help them pass the time. That is how we've started the handicraft project ... So, I joined this group actively and from the first moment when I got here [in Belgrade] the only place where I didn't feel like a refugee was the Women in Black, so Jadranka and I are among the refugees who became activists here.

Despite their scarce financial resources, some women's groups in Zagreb and Belgrade have found ways to hire some refugee women to work part-time in the women's centres. In such cases, preference is given to women of diverse ethnic backgrounds or women survivors of sexual violence and abuse in war, since those women live under particular pressure in both Croatia and Serbia.

According to the policy of these women's groups, all women who work at the centres share the identity of "woman," so the differences in their experience do not make "walls" between them.
Amina, a Bosnian Muslim refugee from Sarajevo, told me that she had met volunteers from the Belgrade Women's Centre when they came to visit her refugee camp. They brought presents for all the women and children, spoke with them, played with the children, and encouraged women not to wait for another visit, but to come to the Centre themselves. Subsequently, Amina had decided to go and visit them since she was getting more and more depressed and disoriented in her difficult life of caring for two children, while her husband and all her family were still in Sarajevo. She felt that she might find someone friendly among these women to speak with about her problems. Now Amina works parttime at the Autonomous Women's Centre; she explained what the experience means to her:

I know that they think the way I do, and that they are pacifists ... But not just that. When I fled to Belgrade I was very frightened. I wondered how I would be received. But everything went normally, no one asked me anything ... I have never declared my nationality officially, I haven't written it down, but naturally, my first name and my father's name show that I am Muslim. I was given the refugee status without difficulties. But inside, I can't describe this terrible fear, precisely because I' $m$ in an environment [the center for refugee women and children with special needs, where the vast majority of women are Serbs] where the women are traumatized, they have lost their husbands, children-their husbands are at the front. They take sides, they are nationally oriented, committed ... It took me a long time, but they've accepted me finally. I think, I might be wrong, but since I've started working here at the Centre, they treat me differently, because they've seen that other women respect me ... Now I'm trying to go to Sweden or the U.S. through the UNHCR. And that's my only chance of leaving and getting together with my husband again. I'm the one making the decisions now. It took me a long time to understand that I wasn't both father and mother to the children, just their mother. I kept thinking: what would he say? But working at the Centre, these women have

Refuge, Vol. 14, No. 8 (January 1995) 
given me self-confidence. I've realized that I'm a mother, and that I have to make the decisions. That I am the one who must decide what's good and what isn't.

As I have argued elsewhere (Korac, in press), due to the political action of local women's groups (as well as the support and action of women's groups worldwide), rape in war has become a global human rights issue in the wake of the conflict in the former Yugoslavia. Unfortunately, the attempt to protect women's human rights and to pressure international institutions to prosecute rape as a war crime has been manipulated by local governments, politicians, and nationalists, as well as by local and international media. Local nationalist propaganda gives incomplete, one-sided information about the rape of women in the Yugoslav wars. Reports focus almost exclusively on the crimes of the "other" side, creating the context for public debates on whether "our" women at an advanced was reached concerning this matter (Zajovic 1993, 98):

We support the demand of the feminist group from Zagreb that rape be recognized as a war crime and prosecuted in accordance with the Geneva Convention, as well as the demand that asylum for raped women be granted in all war-torn areas.

This agreement was signed by women activists from Zagreb, Croatia (Women's Help Now, AZKD), from Ljubljana, Slovenia (S.O.S., Women Against War), from Belgrade, Serbia (S.O.S., Women in Black, Women's Lobby), and from Prishtine, Province of Kosovo (activists from the women's section of the Kosova Democratic League).

Despite the unfavourable political circumstances, women's groups keep protesting against the war, governmental manipulation of refugees' rights, and manipulation of rights of refugee women in particular. ${ }^{13}$ They

\section{Unfortunately, the attempt to protect women's human rights and to pressure international institutions to prosecute rape as a war crime has been manipulated by local governments, politicians, and nationalists, as well as by local and international media.}

stage of pregnancy should be allowed to have an abortion so that they do not carry "the enemy's seed in their wombs." This manipulation focuses on the ethnic membership of the rapist and the fetus as the central issue, rather than on the raped women themselves or the actual crime. In such a context, women's right to abortion takes the form of an almost military intervention and becomes, as Zajovic (1994, 75-76) remarked, an important component in the military strategy of territorial "cleansing." 12

Women's and peace groups from different parts of the former Yugoslavia have protested against the manipulation of sexually abused and tortured women in order to intensify ethnic hatred and war propaganda. At the international conference "Women in Eastern Europe," held in Prague in October 1992, the following agreement also keep records of refugee women's testimonies about violations of their rights, and their sufferings. As stated in a Report of the Centre for Women War Victims (Belic, 13), ${ }^{14}$ since the military conflicts between Bosnian Muslims and Croats in Central Bosnia started, Croatian politicians and government representatives have on several occasions made public statements threatening Bosnian refugee women and children. This, combined with the heated mass media, has induced enormous fear among refugees and added to the atmosphere of insecurity in Croatia. In July, the situation was aggravated when the Croatian police surrounded many camps, entered them abruptly, and claimed to be searching for arms, war deserters, and criminals. They also invaded women's and children's rooms and searched their private property. The Special UN
Reporter, Tadeusz Mazowiecki, told a press conference that between 200 and 500 people were taken from camps to an unknown destination in Herzegovina. Amongst them were women and unaccompanied boys under 15 years of age. Belic and Kesic have stated in their report (p. 13) that

[i]n that period, although we did alarm all the national and international human rights and refugee protection organizations, all we could really do for our women was to go to the camps and support and comfort them.

In Serbia, refugee rights have been similarly violated, and refugees have been manipulated by political elites. From January to April 1994, when it became clear that the so-called "Serbian territories" in Bosnia and Herzegovina could not be "defended" without adequate military personnel, ethnic Serb refugees who fled from Croatia and Bosnia-Herzegovina were forcibly taken to the front (Zajovic 1994). This forced mobilization was carried out with the tacit consent and cooperation of the Serbian government. The action was mainly targeted at refugees living in refugee camps. Women's groups protested this violation of refugee rights on the streets of Belgrade; they also petitioned the government against the forced mobilization of refugees, appealed to the citizens of Belgrade and Serbia for support, and alerted UNHCR officials in Belgrade. However, the UNHCR and women's groups were only able to advise refugees to evade a call for mobilization and to hide somewhere (Aleksov 1994).

One of the purposes of this brief overview of the work of women's groups with refugees, and refugee women in particular, in the former Yugoslavia is to urge a wide international recognition and practical support of their efforts. However, I also wish to emphasize the need for a balanced and differentiated approach to a policy of refugee protection. In the context of ethnic and political turmoil, an effort to find solutions to the problems that force refugees to flee, and ways to 
protect them, means to support strongly local autonomous groups with clear anti-war and anti-nationalist politics. Such groups, including the women's groups mentioned in this paper, work energetically and often without regard for their personal safety to make possible the psychological, social, political, and economic reintegration of refugees from the wartorn regions. Without such support, humanitarian agencies and NGOs (which follow conventional refugee policies that were created to address refugee problems resulting from a different, i.e. post-Second World War, political context) will be increasingly unable to provide protection to those who need it.

\section{Notes}

1. The economic crisis began in the former Yugoslavia in late 1980s as a result of the cumulative effect of hidden inadequacies in the system. Incompetent radical economic reforms resulted in a drastic fall of the GNP in 1989, a full three years prior to the beginning of the war at an average yearly rate of 18.7 percent. [Note: the data presented are taken from a study done by Posarac, Bogosavljevic, and Kovacevic of the Economic Institute in Belgrade. The study was requested and financed by the International Federation of Red Cross and Red Crescent (Vreme, November, 1994).]

2. Exceptions are the governments of Slovenia and of the Former Yugoslav Repub. lic of Macedonia. The vast majority of the refugees and displaced persons within the region are in Croatia, Bosnia-Herzegovina, and Serbia. For exact figures, see Human Rights Worldwide, 1, Vol. 4, March 1994.

3. The Anti-War Campaign Croatia was launched in July 1991 as a coalition of environmental, women's, and civil rights groups to promote non-violence, neutrality, and civic initiatives. In October 1991 the Women in Black Organization was established in Belgrade. Modelled on a group which emerged during the occupation of Palestine, this group meets every Wednesday afternoon for one hour on a street in the centre of Belgrade, silently protesting against the war. Together with the Centre for Anti-War Action of Belgrade, they have held candle vigils in front of the Serbian Parliament for five months in solidarity with all victims in the war. Women's groups, with the support of European and North
American peace and feminist organizations, also initiated and established centres to help and work with women refugees and women who are victims of sexual violence in the war. Women have organized themselves locally in an attempt to give trained counselling and assistance to women who are victims of sexual violence in the war. For more information on anti-war activities of women's groups, see the collection of documents and essays Women for Peace (Zajovic, 1993).

4. Unpublished, distributed through the women's group network in Belgrade.

5. The discussion of the activities of women's groups stems from my field work (June-August 1994) in Belgrade, where I interviewed women activists as well as women refugees. The information on the activities of women's groups in Zagreb was gathered from reports distributed through their networks and meetings during the past year.

6. In Serbia, for example, 83 percent of the adult refugee population are women, and 65 percent of refugee families are headed by women (Milosavljevic 1993).

7. Some of the women's centres which have established a network of cooperation in the former Yugoslavia are: in Belgrade, Serbia - S.O.S. Hotline for Women and Children Victims of Violence, Autonomous Women's Centre, Centre for Girls, Women in Black; in Novi Sad, Serbia S.O.S. Hotline for Prevention of Violence; in Pancevo, Serbia - Women's Centre "Isidora;" in Nis, Serbia - S.O.S. Hotline for Women and Children Victims of Violence; in Zagreb, Croatia - Centre for Women Victims of Violence in War, Women's Info-centre; in Pula, Croatia Autonomous Women's Centre; in Ljubljana, Slovenija - S.O.S. Hotline for Women and Children Victims of Violence; in Celje, Slovenija - Autonomous Women's Centre; in Sarajevo, BosniaHerzegovina - Women's Lobby; Banja Luka, Bosnia-Herzegovina - Centre for Victims of Violence in War; in Skopje, Macedonia - Women of Skopje.

8. All financial help and almost all the moral support for these groups come as a result of solidarity and networking between women's groups worldwide.

9. In Serbia, for example, a vast majority of refugees, 95 percent are placed in host families (Milosavljevic, 1993).

10. The products are being sold through women's groups' networks in Europe and North America; the proceeds go to refugee women.

11. All names of the refugees have been changed for their protection.
13. "Cleansing" is a common lay term for abortion in Serbo-Croatian. Pavicevic, a prominent Belgrade playwright and a member of the Belgrade Circle of Independent Intellectuals (a citizens' alliance founded in 1991), published an article in the Belgrade independent weekly magazine Vreme (January, 1993), entitled "Cleansing." In discussing "cleansing the territories" and "ethnic cleansing" as a newly-conceptualized military strategy in the war in the former Yugoslavia, she mentioned that women will easily understand the painful meaning of the term since "cleansing," a term for abortion, is a part of women's experience.

14. Whenever women's groups in the former Yugoslavia have protested against the war, or have tried to initiate a dialogue or political action intended to maintain solidarity across ethnic boundaries, they have been publicly accused of betraying their ethnic collective. As an example, five Croatian feminists (prominent writers and journalists) were attacked in the Croatian media for publicly demanding an end to the use of female victims of rape by the nationalist propaganda machine. (Images and words of the women who had been raped were used to whip up ethnic hatred.) In the influential Croatian newspaper Globus, in an article entitled "Croatia's Feminists Rape Croatia!," the five feminists were accused of "turning against women in Bosnia and Herzegovina" because they were "concealing Serbian raping of Muslim and Croatian women." The article stated that "it is not the women who have been raped, it is the Croatian and Muslim women who have been raped." Calling them "witches," the article stressed their "communist background" and choice of Serbian partners:

"Almost without exception, they were little girls of communism! The girls from the families of the informers, policemen, guards in prisons, diplomats, high Party and political functionaries. The few who, in spite of their theoretical position and physical appearance did succeed to find a partner for marriage, chose someone according to the official Yugoslav standards: a Serb from Belgrade by Rada Ivekovic, a Serb (two times) from Croatia by Slavenka Drakulic and a Serb from Croatia by Jelena Lovric. It would be immoral to mention these facts were it not, when one looks at it now, a matter of systematic political choice rather than the accidental love choice!" (Globus, December 10, 1992, unsigned, translated by feminists from Zagreb, distributed through the feminist network in Europe).

Continued on page 25/Women's Groups 